\title{
Implementing new northernmost records to modelling the distribution of Hypsiboas caingua (Anura: Hylidae) in South America
}

\author{
Delatorre, M. ${ }^{a *}$, Vasconcelos, TS. ${ }^{b}$, Cunha, NL. ${ }^{a}$, Martins, FI. ${ }^{a}$, Oda, FH. ${ }^{c}$, \\ Aoki C. ${ }^{d}$ and Landgref-Filho, P. $^{d}$ \\ aPrograma de Pós-graduação em Ecologia e Conservação, Centro de Ciências Biológicas e da Saúde, Universidade Federal \\ de Mato Grosso do Sul - UFMS, Cidade Universitária, s/n, CP 549, CEP 79070-900, Campo Grande, MS, Brazil \\ ${ }^{\text {b}}$ Departamento de Ciências Biológicas, Faculdade de Ciências de Bauru, Universidade Estadual Paulista Júlio de \\ Mesquita Filho - UNESP, Av. Eng. Luiz Edmundo Carrijo Coube, 14-01, CEP 17033-360, Bauru, SP, Brazil \\ 'Núcleo de Pesquisas em Limnologia, Ictiologia e Aqüicultura, Laboratório de Ictioparasitologia, Programa de \\ Pós-graduação em Ecologia de Ambientes Aquáticos Continentais, Universidade Estadual de Maringá - UEM, \\ Av. Colombo, 5790, Bloco G-90, CEP 87020-900, Maringá, PR, Brazil \\ ¿Universidade Federal de Mato Grosso do Sul - UFMS, Campus Universitário de Aquidauana - CPAQ, \\ Av. Oscar Trindade de Barros, 740, Unidade II, CEP 79200-000, Aquidauana, MS, Brazil \\ *e-mail: milenadelatorre@gmail.com
}

Received: April 4, 2013 - Accepted: June 19, 2013

(With 2 figures)

\begin{abstract}
New northwestern records of the striped treefrog Hypsiboas caingua (Carrizo, 1991 "1990") are presented for Brazil, extending its known geographic distribution approximately $115 \mathrm{~km}$ northward (linear distance) of the previous northernmost record of the species. In all new localities, individuals of $H$. caingua were only found in calling activity under temperatures below $18^{\circ} \mathrm{C}$. The species appears to be associated with Atlantic Forest, although it had already been recorded in Cerrado. Although the scientific literature data suggests that $H$. caingua presents discontinuous geographical distribution, three methods of distribution modelling based on climatic data show that the species' distribution is continuous. The gap in the distribution may be related to the lack of field surveys in the regions that connect these populations, especially in colder periods. Nevertheless, factors other than climate might also be responsible for the current distribution of $H$. caingua, since the species was absent in well-surveyed sites situated between the areas of modeled distribution. Therefore, further studies on natural history, populations' genetic structure, and geographic distribution models implementing factors other than climate will be important to elucidate some ecological and evolutionary aspects of the distribution of H. caingua in South America.
\end{abstract}

Keywords: Central-Southern Brazil, Cerrado, striped treefrog, species distribution modelling (SDM), low temperatures.

\section{Uso de novos registros ao norte para a modelagem de distribuição de Hypsiboas caingua (Anura: Hylidae) na América do Sul}

\begin{abstract}
Resumo
Novos registros da perereca Hypsiboas caingua (Carrizo, 1991 “1990”) são apresentados para o noroeste do Brasil, ampliando sua distribuição geográfica em aproximadamente $115 \mathrm{~km}$ ao norte (distância linear) em relação ao registro anterior setentrional da espécie. Em todas as novas localidades, indivíduos de $H$. caingua foram apenas encontrados vocalizando sob temperaturas abaixo de $18^{\circ} \mathrm{C}$. A espécie aparenta estar associada com a Mata Atlântica, embora já tenha sido registrada no Cerrado. Apesar de dados da literatura científica sugerirem que H. caingua apresente distribuição geográfica descontínua, os três métodos de modelagem de distribuição, baseados em dados climáticos demonstram que a distribuição da espécie é contínua. A lacuna na distribuição pode estar relacionada à ausência de levantamentos de campo nas regiões que conectam essas populações, principalmente em períodos frios. Contudo, outros fatores além do climático também podem ser responsáveis pela atual distribuição de $H$. caingua, visto a ausência da espécie em locais bem amostrados situados entre as áreas de distribuição modeladas. Portanto, mais estudos sobre a história natural, genética de populações e modelos de distribuição geográfica que abordem outros fatores além do clima, serão importantes para elucidar alguns aspectos ecológicos e evolucionários da distribuição de H. caingua na América do Sul.
\end{abstract}

Palavras-chave: Centro-Sul do Brasil, Cerrado, striped treefrog, modelagem de distribuição de espécie (SDM), baixas temperaturas. 


\section{Introduction}

Hypsiboas (Hyla) caingua is a recently revalidated species (with 30 other species) included in the H. pulchellus group (Faivovich et al., 2005). This species is relatively small size (mean total length $33.7 \mathrm{~mm}$ ), thin legs, and underdeveloped adhesive disks. The dorsal color pattern varies from whitish to brown with three thin longitudinal lines, and a dark lateral stripe from the snout to the posterior surfaces of the flanks, where it is replaced by a dark color. The posterior part of the thighs is whitish with dark blotches (Carrizo, 1990).

The current distribution of $H$. caingua encompasses the provinces of Misiones (type locality) and Corrientes, northeastern Argentina (Carrizo, 1990; Garcia et al., 2007a), and adjacent areas in southeastern Paraguay (Brusquetti and Lavilla, 2006). In addition, there are isolated populations in Brazil located in the states of São Paulo (Melo et al., 2007; Condez et al., 2009; Toledo and Haddad, 2009; Brassaloti et al., 2010; Araujo and Almeida-Santos, 2011; Maffei et al., 2011), Rio Grande do Sul (Garcia et al., 2007b; Lema and Martins, 2011) and Mato Grosso do Sul (municipalities of Tacuru and Naviraí: Aoki et al., 2010). Herein, we provide new records of $H$. caingua from Mato Grosso do Sul state, Brazil, representing the northernmost records of the species in South America. In addition, we present an overview map of its current geographical distribution, and determine potential areas of occurrence using species distribution modelling (SDM) methodologies.

\section{Material and Methods}

Throughout herpetofaunal surveys in Mato Grosso do Sul, we recorded nine new points of occurrence for $H$. caingua (Table 1), and collected four males as voucher specimens, deposited in the Coleção Zoológica da Universidade Federal de Mato Grosso do Sul (ZUFMS), Campo Grande, Mato Grosso do Sul, Brazil (ZUFMSAMP2503, ZUFMS-AMP2504, ZUFMS-AMP2505, ZUFMS-AMP2506 - permission of IBAMA: 011/2010 and process no. 02014.000112/2011-06; permits: 013/2010, process no. 02014.000111/2011-53). Point occurrence data obtained from our new records and literature (Appendix 1) were used to generate potential distribution areas using three SDM methodologies, which are widely used in the literature (e.g., Giovanelli et al., 2010; Terribile et al., 2010; Vasconcelos et al., 2012). BIOCLIM characterizes sites that are located within the environmental hyperspace occupied by a species, in which the potential climatic domain is the multidimensional envelope that encompasses all recorded locations of the species (Nix, 1986). OM-GARP is a version of GARP (Anderson et al., 2003) implemented in openModeller 1.1.0 software (Muñoz et al., 2011), which uses a genetic algorithm to select a set of rules that best predicts the species' distributions (Stockwell and Peters, 1999). Support Vector Machines (SVM) are a class of nonprobabilistic statistical pattern recognition that estimate the boundary of the set from which a collection of observations is drawn, minimizing errors of empirical classifications and maximizing the geometric boundaries (De Marco-Junior and Siqueira, 2009; Giovanelli et al., 2010). The environmental variables used to model species distributions were taken from the WorldClim database (Hijmans et al., 2005) and selected to describe general climatic trends (i.e. mean values), variation in temperature and precipitation over time, and potential physiological limits for amphibians (Nix, 1986): annual mean temperature, temperature seasonality, minimum temperature of the coldest month, temperature annual range, annual precipitation, precipitation seasonality, and precipitation of the warmest quarter $(10 \mathrm{~km}$ spatial resolution). The SDM of each model was evaluated by the receiver operating characteristic (ROC) curve, whose area under the curve (AUC) ranges from 0.5 (random prediction) to 1 (sufficiently discriminatory prediction) (Elith and Burgman, 2002). Finally, two consensus maps were generated in openModeller 1.1.0 (Muñoz et al., 2011) in order to consider, based on the three SDM methodologies, the most probable occurrence area for H. caingua in South America. The first consensus map considered a probability of $50 \%$ of occurrence considering all SDM methods, while the second map considered a more restrictive threshold of $70 \%$. All SDM methods were performed in openModeller 1.1.0 (Muñoz et al., 2011).

Table 1. Characterizations of point data occurrence of Hypsiboas caingua in Mato Grosso do Sul state, Brazil. The localities' sequence corresponds to north-south direction ("Datum WGS 84").

\begin{tabular}{|c|c|c|c|}
\hline Municipality & $\begin{array}{c}\text { Coordinates } \\
\text { (lat., long.) } \\
\end{array}$ & Environment & Temperature $\left({ }^{\circ} \mathrm{C}\right)$ \\
\hline Nova Alvorada do Sul & $21^{\circ} 34^{\prime} 41^{\prime \prime} \mathrm{S} ; 54^{\circ} 13^{\prime} 56^{\prime \prime} \mathrm{W}$ & Swamp areas & 12 \\
\hline Rio Brilhante & $21^{\circ} 51^{\prime} 08^{\prime \prime} \mathrm{S} ; 54^{\circ} 00^{\prime} 54^{\prime \prime} \mathrm{W}$ & Permanent ponds & 18 \\
\hline Bela Vista & $22^{\circ} 01^{\prime} 53^{\prime \prime} \mathrm{S} ; 55^{\circ} 52^{\prime} 33^{\prime \prime} \mathrm{W}$ & Swamp areas & 16 \\
\hline Angélica & $22^{\circ} 03^{\prime} 46^{\prime \prime} \mathrm{S} ; 53^{\circ} 47^{\prime} 53^{\prime \prime} \mathrm{W}$ & Permanent ponds & 17 \\
\hline Ponta Porã & $22^{\circ} 16^{\prime} 56^{\prime \prime} \mathrm{S} ; 55^{\circ} 07^{\prime} 07^{\prime \prime} \mathrm{W}$ & Swamp areas & 15 \\
\hline Fátima do Sul & $22^{\circ} 18^{\prime} 59^{\prime \prime} \mathrm{S} ; 54^{\circ} 35^{\prime} 15^{\prime \prime} \mathrm{W}$ & Swamp areas & 16 \\
\hline Ivinhema & $22^{\circ} 25^{\prime} 58^{\prime \prime} \mathrm{S} ; 53^{\circ} 53^{\prime} 58^{\prime \prime} \mathrm{W}$ & Permanent ponds & 18 \\
\hline Vicentina & $22^{\circ} 29^{\prime} 04^{\prime \prime} \mathrm{S} ; 54^{\circ} 23^{\prime} 31^{\prime \prime} \mathrm{W}$ & Swamp areas & 18 \\
\hline Amambaí & 22॰59’39”S; 5455’55”W & Permanent ponds & 18 \\
\hline
\end{tabular}




\section{Results}

The record of H. caingua in Nova Alvorada do Sul municipality, Brazil, expands its distribution to approximately $115 \mathrm{~km}$ (linear distance) northward (previously northernmost record was between Gália and Alvilândia municipalities, São Paulo - 22²4'11' S; 4942'05" W - Brassaloti et al., 2010) and reaches into the Cerrado phytogeographic domain of Mato Grosso do Sul state, Brazil (Figure 1).

In all new localities, individuals of $H$. caingua were only found in calling activity under temperatures below $18^{\circ} \mathrm{C}$ (Table 1). Each male was observed in calling activity over shrubs and aquatic vegetation, perched in branches and leaves varying from $20 \mathrm{~cm}$ to one meter height.

Considering the current extent of distribution of H. caingua in South America and specifically in Brazil (Figure 1A and 1B, respectively), all SDM methods show reasonable congruence with the current species' distribution (Figure 2A, 2B and 2C). Among the three methods, BIOCLIM provided the smallest predicted occurrence area, SVM provides the largest, and OM-GARP an intermediary foreseen occurrence area (Figure 2). Both consensus maps (Figure 2D and 2E) show high probability of occurrence of H. caingua in the Cerrado and Atlantic Forest, which includes all extent of occurrence of the current species' distribution, but higher probabilities of occurrence mostly include the western region of Paraná state, south of Mato
Grosso do Sul state, southeastern Paraguay, and Misiones Province in Argentina (Figure 2D and 2E).

\section{Discussion}

The record of $H$. caingua in the municipality of Nova Alvorada do Sul, Brazil, is the northernmost record of H. caingua in South America. Furthermore, this record extends the known distribution of $H$. caingua in $155 \mathrm{~km}$ (linear distance) northward from the nearest occurrence in Mato Grosso do Sul state, recorded in the municipality of Naviraí (Aoki et al., 2010). Despite the limited knowledge about the biology and ecology of H. caingua (e.g., Melo et al., 2007; Kolenc et al., 2008; Brassaloti et al., 2010), the species appears to be predominantly associated with the Atlantic Forest domain in the São Paulo state (Araújo et al., 2009; Condez et al., 2009; Rossa-Feres et al., 2011). However, the species had already been recorded in open area formations in São Paulo state, i.e. Cerrado (Melo et al., 2007; Araujo and Almeida-Santos, 2011; Valdujo, 2011), but its record in Nova Alvorada do Sul and Bela Vista are the first reports of this species in the Cerrado of Mato Grosso do Sul state, Brazil. Besides, $H$. caingua also occurs in the mixed ombrophilous forest in the brazilian southern states, open natural fields in Argentina (provinces of Misiones and Corrientes) and in

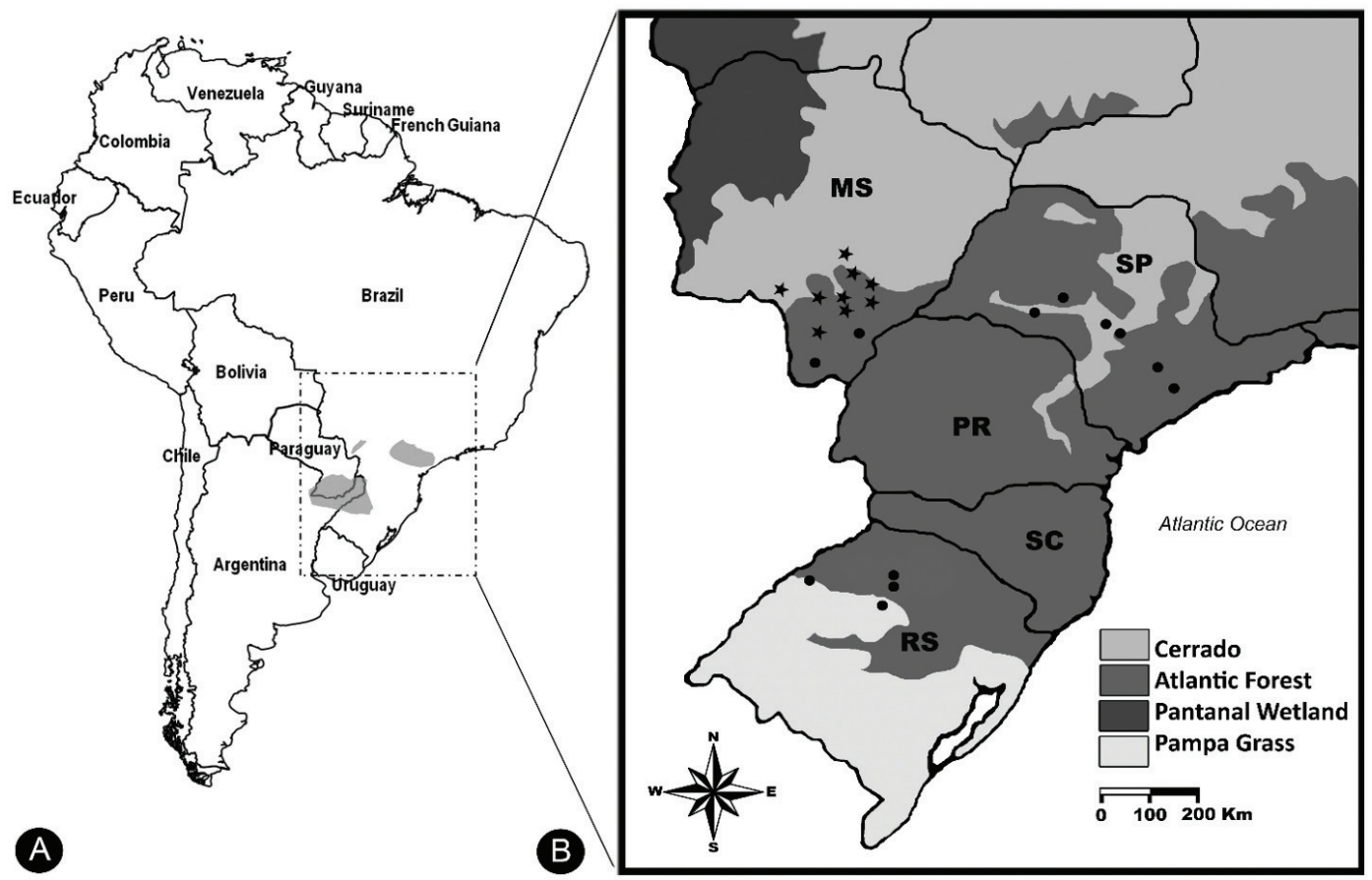

Figure 1. (A) Known geographical distribution of H. caingua in South America (modified from Scott et al. (2004)); (B) and the reported occurrence of the species in central-southern Brazil (Acronym of the states - MS: Mato Grosso do Sul; SP: São Paulo; RS: Rio Grande do Sul; PR: Paraná and SC: Santa Catarina) (circles - Garcia et al., 2007b; Melo et al., 2007; Condez et al., 2009; Toledo and Haddad, 2009; Aoki et al., 2010; Brassaloti et al., 2010; Araujo and Almeida-Santos, 2011; Maffei et al., 2011). Stars represent the news records in Mato Grosso do Sul state Brazil. Brazilian phytogeographic domains accordingly to IBGE (2011). 

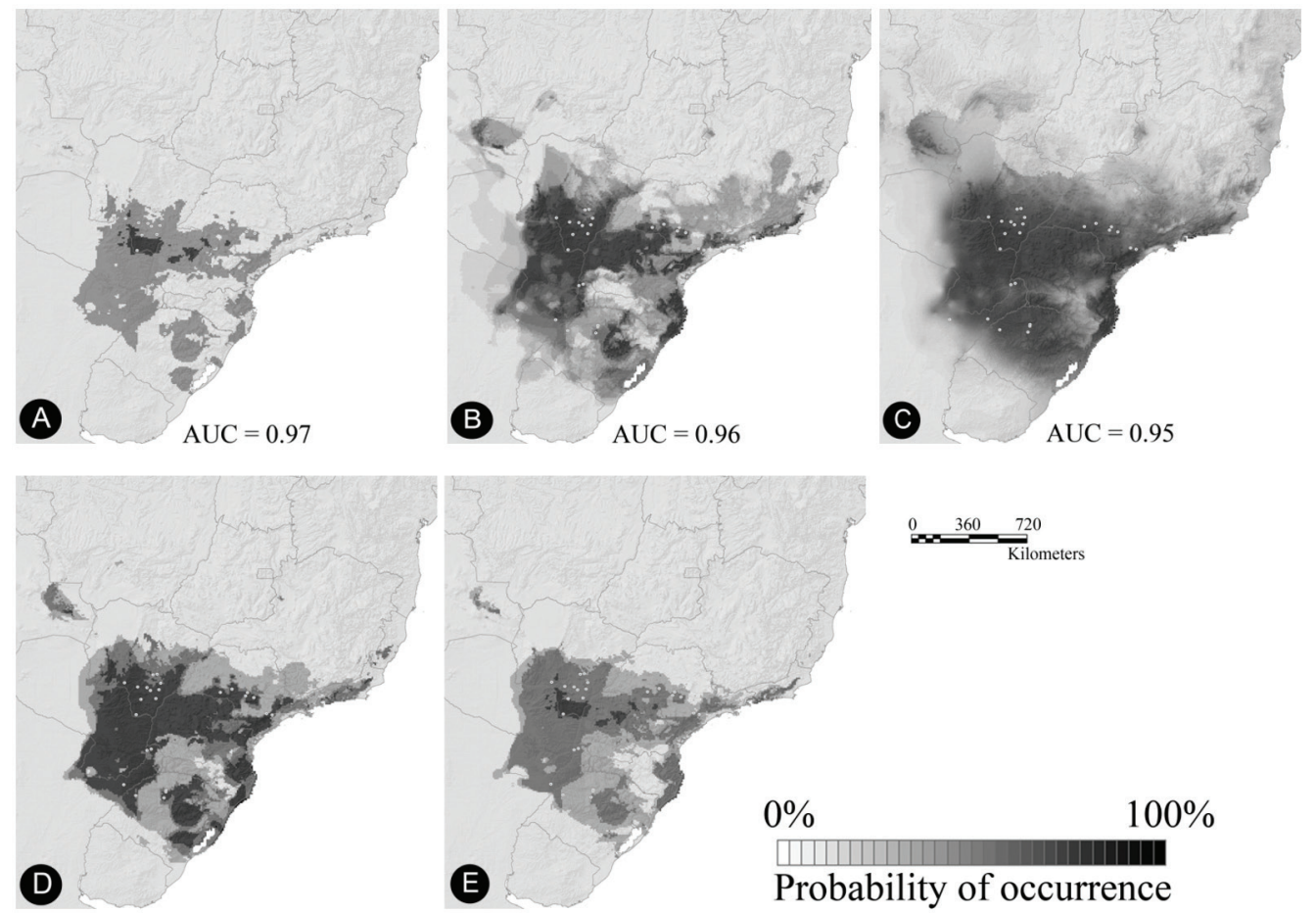

Figure 2. Predicted occurrence areas for Hypsiboas caingua: (A) BIOCLIM prediction, (B) OM-GARP prediction, (C) SVM prediction, (D) Consensus map considering a threshold of 50\%, and (E) consensus map considering a threshold of $70 \%$. $\mathrm{AUC}=$ Area Under the Curve for model validation (see Methods). White dots represent the 26 occurrence records used in the modeling process (see Appendix 1).

the humid chaco ecoregion of Argentina and Paraguay (Garcia et al. 2007a).

Considering the new records, males of $H$. caingua were only found in calling activities under low temperatures, which reinforces the hypothesis of adaptation to low temperatures (Melo et al., 2007). Even though the species may congregate for breeding throughout the year, with decrease in abundance on nights with temperatures below $15^{\circ} \mathrm{C}$ (Brassaloti et al., 2010), we recorded calling activities at even lower temperatures in Nova Alvorada do Sul ( $\sim 8$ $15^{\circ} \mathrm{C}$ ). All males were calling perched over shrubs and aquatic vegetation, in agreement with Jim (1980), but Melo et al., (2007) also found males calling on the floor.

The current distribution of $H$. caingua, also considering our records, clearly shows discontinuity with a gap among the isolated populations in Paraguay, Argentina, Rio Grande do Sul state (Brazil), and the most occurrence points in São Paulo and Mato Grosso do Sul states, Brazil. The three SDM methods pointed out that the most probable occurrence areas represent the current records in Brazil (states of Mato Grosso do Sul, São Paulo, and Rio Grande do Sul), southeastern Paraguay and Misiones Province in Argentina. However, all SDM maps showed continuity on the occurrence of $H$. caingua, except for the low probability of occurrence area between the states of Rio Grande do Sul and central Paraná (southern Brazil). It intuitively suggests that the current gap on the distribution (western and north-western regions of São Paulo and Paraná states, respectively) is because of the lack of anurans surveys in these regions, mainly in cold periods, as reported herein. Nevertheless, SDM methodologies, as they were performed herein, are not able to predict absences caused by other factors than climate (e.g. biotic interactions and evolutionary history). Rather, SDM methods consequently provided only those suitable areas where $H$. caingua would be able to occupy. Then, other factors than climate might be also responsible in the current distribution of $H$. caingua, since well surveyed sites between the current records, which have higher probabilities of occurrence according to the species distribution modelling, have no occurrence record for this species (e.g., Bernarde and Machado, 2001; Vasconcelos and Rossa-Feres, 2008; Serafim et al., 2008; Santos et al., 2009; Armstrong and Conte, 2010; Conte et al., 2010; Forlani et al., 2010; Silva and RossaFeres, 2011; Sabbag and Zina, 2011). We believe that further studies on natural history, populations' genetic structure and geographic distribution models implementing other factors than climate will be important to elucidate some ecological and evolutionary aspects of the distribution of H. caingua in South America.

\section{Acknowledgements}

M. Delatorre thanks The Coordenação de Aperfeiçoamento de Pessoal de Nível Superior (CAPES) for the research support, T. S. Vasconcelos thanks Fundação de Amparo 
à Pesquisa do Estado de São Paulo (FAPESP, grant 2011/18510-0) for the research support; N. L. Cunha thanks Fundação de Apoio ao desenvolvimento do Ensino, Ciência e Tecnologia do Estado de Mato Grosso do Sul (FUNDECT, grant $\mathrm{N}^{\circ} 22 / 2010$ ) and CAPES (grant $\mathrm{n}^{\circ}$ BEX 4915/13-5) for the research support and F. H. Oda thanks CAPES provided financial support. The authors are thankful to Jeff (Himmelstein, J.) for English reviewing.

\section{References}

ANDERSON, RP., LEW, D. and PETERSON, AT., 2003. Evaluating predictive models of species' distributions: criteria for selecting optimal models. Ecological Modelling, vol. 162, no. 3, p. 211-232. http://dx.doi.org/10.1016/S0304-3800(02)00349-6.

AOKI, C., LANDGREF-FILHO, P., SOUSA, DLH., ODA, FH., GAMARRA, RM. and SOUZA, FL., 2010. Hypsiboas caingua. Herpetological Review, vol. 41, p. 507.

ARAÚJO, OGS., TOLEDO, LF., GARCIA, PCA. and HADDAD, CFB., 2009. The amphibians of São Paulo State, Brazil amphibians of São Paulo. Biota Neotropica, vol. 9, no. 4, p. 197-209. http:// dx.doi.org/10.1590/S1676-06032009000400020.

ARAUJO, CO. and ALMEIDA-SANTOS, SM., 2011. Herpetofauna in a cerrado remnant in the state of São Paulo, Southeastern Brazil. Biota Neotropica, vol. 11, no. 3, p. 47-62. http://dx.doi. org/10.1590/S1676-06032011000300003.

ARMSTRONG, CG. and CONTE, CE., 2010. Assemblage of anurans (Amphibia, Anura) of an area of Atlantic Forest, South of Brazil. Biota Neotropica, vol. 10, no. 1, p. 39-46. http://dx.doi. org/10.1590/S1676-06032010000100003.

BERNARDE, PS. and MACHADO, RA., 2001. Riqueza de espécies, ambientes de reprodução e temporada de vocalização da anurofauna em Três Barras do Paraná, Brasil (Amphibia: Anura). Cuadernos de Herpetologia, vol. 14, p. 93-104.

BRASSALOTI, RA., ROSSA-FERES, DC. and BERTOLUCI, J., 2010. Anuran fauna of the Semi-deciduous Forest of the Estação Ecológica dos Caetetus, Southeastern Brazil. Biota Neotropica, vol. 10 , no. 1 , p. $275-292$. http://dx.doi.org/10.1590/S167606032010000100024

BRUSQUETTI, F. and LAVILLA, EO., 2006. Lista comentada de los anfibios de Paraguay. Cuadernos de Herpetologia, vol. 20 , p. 3-79.

CARRIZO, GR., 1990. Sobre los hilidos de Misiones, Argentina, com la descripcion de una nueva especie, Hyla caingua n.sp. (Anura, Hylidae). Cuadernos de Herpetologia, vol. 5, no. 6, p. 32-39.

CONDEZ, TH., SAWAYA, RJ. and DIXO, M., 2009. Herpetofauna of the Atlantic Forest remnants of Tapiraí and Piedade region, São Paulo state, southeastern Brazil. Biota Neotropica, vol. 9, p. 157-185. http://dx.doi.org/10.1590/S1676-06032009000100018.

CONTE, CE., NOMURA, F., MACHADO, RA., KWET, A., LINGNAU, R. and ROSSA-FERES, DC., 2010. New records in the geographic distribution range of the anurans of the Araucaria Forest and considerations on their vocalizations. Biota Neotropica, vol. 10, p. 201-224. http://dx.doi.org/10.1590/S167606032010000200024

DE MARCO-JUNIOR, P. and SIQUEIRA, MF., 2009. Como determinar a distribuição de espécies sobre uma abordagem conservacionista. Megadiversidade, vol. 5, p. 65-76.
ELITH, J. and BURGMAN, M., 2002. Predictions and their validation: rare plants in the Central Highlands, Victoria, Australia. In SCOTT, JM., HEGLUND, PJ., MORRISON, ML., RAPHAEL, MG., WALL, WA. and SAMSON, FB. (Eds.). Predicting species occurrences: Issues of accuracy and scale. Washington: Island Press. p. 303-314.

FAIVOVICH, J., HADDAD, CFB., GARCIA, PCA., FROST, DR., CAMPBELL, JA. and WHEELER, WC., 2005. Systematic review of the frog family Hylidae, with special reference to Hylinae: A phylogenetic analysis and taxonomic revision. Bulletin of the American Museum of Natural History, vol. 294, no. 1, p. 1-240. http://dx.doi.org/10.1206/0003-0090(2005)294[0001:SR OTFF]2.0.CO;2.

FORLANI, MC., BERNARDO, PH., HADDAD, CFB. and ZAHER, H., 2010. Herpetofauna of the Carlos Botelho State Park, São Paulo State, Brazil. Biota Neotropica, vol. 10, no. 3, p. 265-309. http://dx.doi.org/10.1590/S1676-06032010000300028.

GARCIA, PCA., LAVILLA, E., LANGONE, J. and SEGALLA, MV., 2007a. Anfíbios da região subtropical da América do Sul: padrões de distribuição. Ciência \& Ambiente, vol. 35, p. 65-100.

GARCIA, PCA., FAIVOVICH, J. and HADDAD, CFB., $2007 \mathrm{~b}$. Redescription of Hypsiboas semiguttatus, with the Description of a New Species of the Hypsiboas pulchellus Group. Copeia, vol. 2007, no. 4, p. 933-949. http://dx.doi.org/10.1643/00458511(2007)7[933:ROHSWT]2.0.CO;2.

GIOVANELLI, JGR., SIQUEIRA, MF., HADDAD, CFB. and ALEXANDRINO, J., 2010. Modeling a spatially restricted distribution in the Neotropics: How the size of calibration area affects the performance of five presence only methods. Ecological Modelling, vol. 221, no. 2, p. 215-224. http://dx.doi.org/10.1016/j. ecolmodel.2009.10.009.

HIJMANS, RJ., CAMERON, SE., PARRA, JL., JONES, PG. and JARVIS, A., 2005. Very high resolution interpolated climate surfaces for global land areas. International Journal of Climatology, vol. 25 , no. 15 , p. 1965-1978. http://dx.doi.org/10.1002/joc.1276.

Instituto Brasileiro de Geografia e Estatística - IBGE, 2011. Mapa de Biomas do Brasil. Rio de Janeiro, Instituto Brasileiro de Geografia e Estatística. Índice de cartas e mapas. Available from: ftp://ftp.ibge.gov.br/Cartas_e_Mapas/Mapas_Murais/. Access in: 12 jun. 2011.

JIM, J., 1980. Aspectos ecológicos dos anfibios registrados na região de Botucatu, do estado de São Paulo (Amphibia. Anura). São Paulo: Universidade de São Paulo. 332 p. Tese de doutorado em Ciências.

KOLENC, F., BORTEIRO, C., ALCALDE, L., BALDO, D., CARDOZO, D. and FAIVOVICH, J., 2008. Comparative larval morphology of eight species of Hypsiboas wagler (Amphibia, Anura, Hylidae) from Argentina and Uruguay, with a review of the larvae of this genus. Zootaxa, vol. 1927, p. 1-66.

LEMA, T. and MARTINS, LA., 2011. Anfibios do Rio Grande do Sul: catálogo, diagnoses, distribuição, iconografia. Porto Alegre: EDIPUCRS. 196 p.

MAFFEI, F., UBAID, FK. and JIM, J., 2011. Anfibios da Fazenda Rio Claro, Lençóis Paulista, SP, Brasil. Bauru: Canal 6. 128 p.

MELO, GV., ROSSA-FERES, DC. and JIM, J., 2007. Temporal variation in calling site use in a community of anurans in Botucatu, São Paulo State, Brazil. Biota Neotropica, vol. 7, p. 93-102. http:// dx.doi.org/10.1590/S1676-06032007000200011. 
MUÑOZ, MES., GIOVANNI, R., SIQUEIRA, MF., SUTTON, T., BREWER, P., PEREIRA, RS., CANHOS, DAL. and CANHOS, VP., 2011. openModeller: a generic approach to species' potential distribution modelling. Geoinformatica, vol. 15, no. 1, p. 111-135. http://dx.doi.org/10.1007/s10707-009-0090-7.

NIX, HA., 1986. A biogeographic analysis of Australian elapid snakes. In LONGMORE, R. (Ed.). Atlas of elapid snakes in Australia. Canberra, Australia: Australian Government Publishing Service. p. 4-15. Australian Flora and Fauna Series.

ROSSA-FERES, DC., SAWAYA, RJ., FAIVOVICH, J., GIOVANELLI, JGR., BRASILEIRO, CA., SCHIESARI, L., ALEXANDRINO, J. and HADDAD, CFB., 2011. Amphibians of São Paulo State, Brazil: state-of art and perspectives. Biota Neotropica, vol. 11, p. 1-19. http://dx.doi.org/10.1590/S1676-06032011000500004.

SABBAG, AF. and ZINA, J., 2011. Anurans of a riparian forest in Sao Carlos, state of São Paulo, Brazil. Biota Neotropica, vol. 11 , no. 3 , p. 179-188. http://dx.doi.org/10.1590/S167606032011000300015 .

SANTOS, TG., VASCONCELOS, TS., ROSSA-FERES, DC. and HADDAD, CFB., 2009. Anurans of a seasonally dry tropical forest: the Morro do Diabo State Park, São Paulo State, Brazil. Journal of Natural History, vol. 43, no. 15-16, p. 973-993. http:// dx.doi.org/10.1080/00222930802702498.

SCOTT, N., AQUINO, L., KWET, A., PAVAN, D., LAVILLA, E. and BALDO, D., 2004. Hypsiboas caingua. In International Union for Conservation of Nature. IUCN Red List of Threatened Species. Version 2011.2. Available from: $<$ http://www.iucnredlist. org/apps/redlist/details/55425/0>. Access in: 05 Mar. 2013

SERAFIM, H., CICCHI, PJP., IENNE, S. and JIM, J., 2008. Anurans of remnants of Atlantic forest of São José do Barreiro municipality, São Paulo State, Brazil. Biota Neotropica, vol. 8, p. 69-77. http://dx.doi.org/10.1590/S1676-06032008000200007.
SILVA, FR. and ROSSA-FERES, DC., 2011. Influence of terrestrial habitat isolation on the diversity and temporal distribution of anurans in an agricultural landscape. Journal of Tropical Ecology, vol. 27, no. 03, p. 327-331. http://dx.doi.org/10.1017/ S0266467410000842.

STOCKWELL, D. and PETERS, D., 1999. The GARP modelling system: problems and solutions to automated spatial prediction. International Journal of Geographical Information Science, vol. 13, no. 2, p. 143-158. http://dx.doi.org/10.1080/136588199241391.

TERRIBILE, LC., DINIZ-FILHO, JA. and DE MARCO JUNIOR, P., 2010. How many studies are necessary to compare niche-based models for geographic distributions? Inductive reasoning may fail at the end. Revista Brasileira de Biologia = Brazilian Journal of Biology, vol. 70, no. 2, p. 263-269. http://dx.doi.org/10.1590/ S1519-69842010000200005. PMid:20549059

TOLEDO, LF. and HADDAD, CFB., 2009. Defensive vocalizations of Neotropical anurans. South American Journal of Herpetology, vol. 4, no. 1, p. 25-42. http://dx.doi.org/10.2994/057.004.0104.

VALDUJO, PH., 2011. Diversidade e distribuição de anfibios no Cerrado: o papel dos fatores históricos e dos gradientes ambientais. São Paulo: Universidade Federal de São Paulo. 125 p. Tese de doutorado em Ciências.

VASCONCELOS, TS. and ROSSA-FERES, DC., 2008. Habitat heterogeneity and use of physical and acoustic space in anuran communities in Southeastern Brazil. Phyllomedusa, vol. 7, no. 2, p. 127-142. http://dx.doi.org/10.11606/issn.2316-9079.v7i2p127-142.

VASCONCELOS, TS., RODRÍGUEZ, MA. and HAWKINS, BA., 2012. Species distribution modelling as a macroecological tool: a case study using New World amphibians. Ecography, vol. 35, no. 6, p. 539-548. http://dx.doi.org/10.1111/j.1600-0587.2011.07050.x. 
Appendix 1. Geographical coordinate and municipality of known literature occurrence and new records of $H$. caingua used to generate the potential distribution areas by the three SDM methodologies. Acronym of the states - MS: Mato Grosso do Sul; SP: São Paulo; RS: Rio Grande do Sul. The localities' sequence corresponds to north-south direction ("Datum WGS 84 ").

\begin{tabular}{|c|c|c|}
\hline \multirow[t]{2}{*}{ Municipality (State) } & Coordinates & \multirow[t]{2}{*}{ Reference } \\
\hline & (lat., long.) & \\
\hline Nova Alvorada do Sul, MS & $21^{\circ} 34^{\prime} 41^{\prime \prime S} ; 54^{\circ} 13^{\prime} 56^{\prime \prime W}$ & Present study \\
\hline Rio Brilhante, MS & $21^{\circ} 51^{\prime} 08^{\prime \prime} \mathrm{S} ; 54^{\circ} 00^{\prime} 54^{\prime \prime} \mathrm{W}$ & Present study \\
\hline Bela Vista, MS & $22^{\circ} 01 ' 53^{\prime \prime} \mathrm{S} ; 55^{\circ} 52^{\prime} 33^{\prime \prime} \mathrm{W}$ & Present study \\
\hline Angélica, MS & $22^{\circ} 03^{\prime} 46^{\prime \prime S} ; 53^{\circ} 47^{\prime} 53^{\prime \prime} \mathrm{W}$ & Present study \\
\hline Ponta Porã, MS & $22^{\circ} 16^{\prime} 56^{\prime \prime} \mathrm{S} ; 55^{\circ} 07^{\prime} 07^{\prime \prime} \mathrm{W}$ & Present study \\
\hline Fátima do Sul, MS & $22^{\circ} 18^{\prime} 59^{\prime \prime} \mathrm{S} ; 54^{\circ} 35^{\prime} 15^{\prime \prime} \mathrm{W}$ & Present study \\
\hline Between Gália and Alvilândia, SP & $22^{\circ} 24^{\prime} 11^{\prime \prime S} ; 49^{\circ} 42^{\prime} 05^{\prime \prime} \mathrm{W}$ & Brassaloti et al. (2010) \\
\hline Ivinhema, MS & $22^{\circ} 25^{\prime} 58^{\prime \prime} \mathrm{S} ; 53^{\circ} 53^{\prime} 58^{\prime \prime} \mathrm{W}$ & Present study \\
\hline Vicentina, MS & $22^{\circ} 29^{\prime} 04^{\prime \prime S}$; 54²3’31”W & Present study \\
\hline Assis, SP & $22^{\circ} 35^{\prime} 44^{\prime \prime} \mathrm{S} ; 50^{\circ} 21^{\prime} 55^{\prime \prime} \mathrm{W}$ & Araujo and Almeida-Santos (2011) \\
\hline Lençóis Paulista, SP & $22^{\circ} 47^{\prime} 44^{\prime \prime S} ; 48^{\circ} 55^{\prime} 27^{\prime \prime} \mathrm{W}$ & Maffei et al. (2011) \\
\hline Botucatu, SP & $22^{\circ} 53^{\prime} 09^{\prime \prime} \mathrm{S} ; 48^{\circ} 26^{\prime} 42^{\prime \prime} \mathrm{W}$ & Melo et al. (2007) \\
\hline Naviraí, MS & $22^{\circ} 56^{\prime} 43^{\prime \prime} \mathrm{S} ; 54^{\circ} 04^{\prime} 39^{\prime \prime} \mathrm{W}$ & Aoki et al. (2010) \\
\hline Amambaí, MS & 22॰59’39”S; 545'5'”W & Present study \\
\hline Pilar do Sul, SP & $23^{\circ} 48^{\prime} 47^{\prime \prime} \mathrm{S} ; 47^{\circ} 42^{\prime} 59^{\prime \prime} \mathrm{W}$ & Toledo and Haddad (2009) \\
\hline Tacuru, MS & 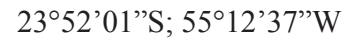 & Aoki et al. (2010) \\
\hline Between Tapiraí and Piedade, SP & $23^{\circ} 53 ’ 20^{\prime} \mathrm{S} ; 4^{\circ} 23^{\prime} 20^{\prime \prime} \mathrm{W}$ & Condez et al. (2009) \\
\hline Iguazú, Misiones & $25^{\circ} 50^{\prime} 53^{\prime \prime} \mathrm{S} ; 54^{\circ} 20^{\prime} 48^{\prime \prime} \mathrm{W}$ & Carrizo (1990) \\
\hline Puerto Bemberg, Misiones & $25^{\circ} 55^{\prime} 10^{\prime \prime} \mathrm{S} ; 54^{\circ} 35^{\prime} 07^{\prime \prime} \mathrm{W}$ & Carrizo (1990) \\
\hline Posada, Misiones & $27^{\circ} 26^{\prime} 12 ’ \mathrm{~S} ; 55^{\circ} 53 ’ 24^{\prime \prime} \mathrm{W}$ & Kolenc et al. (2008) \\
\hline Playadito, Corrientes & $27^{\circ} 53^{\prime} 05^{\prime \prime} \mathrm{S} ; 55^{\circ} 55^{\prime} 11^{\prime \prime} \mathrm{W}$ & Carrizo (1990) \\
\hline Manantiales, Corrientes & $27^{\circ} 55^{\prime} 26^{\prime \prime S} ; 58^{\circ} 06^{\prime} 12^{\prime \prime} \mathrm{W}$ & Carrizo (1990) \\
\hline Condor, RS & $28^{\circ} 12^{\prime} 28^{\prime \prime} \mathrm{S} ; 53^{\circ} 29^{\prime} 14^{\prime \prime} \mathrm{W}$ & Garcia et al. (2007b) \\
\hline Panambi, RS & $28^{\circ} 17^{\prime} 33^{\prime \prime S}$; 5330’06”W & Garcia et al. (2007b) \\
\hline Santo Antônio das Missões, RS & $28^{\circ} 30^{\prime} 40^{\prime \prime} \mathrm{S} ; 55^{\circ} 14^{\prime} 01^{\prime \prime} \mathrm{W}$ & Garcia et al. (2007b) \\
\hline Cruz Alta, RS & $28^{\circ} 38^{\prime} 19^{\prime \prime} \mathrm{S} ; 53^{\circ} 36^{\prime} 23^{\prime \prime} \mathrm{W}$ & Garcia et al. (2007b) \\
\hline
\end{tabular}

